\title{
THE PROBLEM OF REAL ESTATE RESEARCH AREA SELECTION FOR THE PURPOSE OF APPRAISAL PROCESS
}

\author{
Małgorzata Krajewska, Ph.D \\ The Department of Investment and Real Estate \\ Nicolaus Copernicus University in Toruniu \\ Department of Geomatics, Geodesy and Spatial Economy \\ University of Technology and Life Sciences in Bydgoszcz \\ e-mail:gosiak@econ.umk.pl
}

\begin{abstract}
The following article contributes to the discussion on the issue of the interference of legal regulations on the procedure of real estate appraisal, which is as an economic activity. A special dose of attention is drawn to the selection of the research area of the real estate market. Legal regulations referring to this selection as well as, economic factors based on the preferences of buyers have been described.

The application of quality-based methods of marketing has been indicated as a possible means of diagnosing the real estate market, bringing satisfactory results even in the case of limited as well as complex markets, such as suburban areas. On the basis of the Bydgoszcz agglomeration, it was proven that real estate market interference areas do not correlate with the administrative borders of cities or districts.

Furthermore, an appraisal of land located in a suburban area of Bydgoszcz was performed twice by varying means, accepting data from different market areas: local (the territory of the commune) and supralocal (the territory of the commune and partially, the city), thus indicating the considerable influence of research area selection on the estimated value.

The acquired research results may serve as a starting point for further analyses of other local markets.
\end{abstract}

Keywords: area of real estate market, local real estate market, the regional real estate market.

JEL Classification: R33.

Citation: Krajewska M., (2013), "The problem of real estate research area selection for the purpose of appraisal process", Real Estate Management and Valuation, vol. 21, no. 3, pp. 25-34.

DOI: $10.2478 /$ remav-2013-0023.

\section{Introduction}

Analysis of the real estate market is an essential component of any appraisal. The most commonly desired type of value is market value (MSW, 2005), which in Polish legislation has been defined in the Real Estate Act (1997) and in the Universal National Appraisal Principles (UNAP 1). The essence of market value is the search for value as a price hypothesis, understood to be the most probable price, which is typically the most frequently occurring price possible to obtain in market transaction on the day of the appraisal (KUCHARSKA-STASIAK, 2011). The Real Estate Management Act (1997) also indicates the need to base the appraisal process on transaction prices. In a comparative approach, the basis for determining market value is the market evidence acquired from the sale of similar properties.

It is thus necessary to analyze deeds, and the scope of this analysis depends, among others, on the type and location of the property, the purpose and method of appraisal, and the available data on prices and features of similar properties. The spatial range of the analysis, i.e., the market research 
area, will stem from the state of its development; often, the less developed it is, the greater the spatial coverage. At the same time, the legal regulations dealing with real estate management have not defined the concepts of a local or regional market, and the Directive on property appraisal and appraisal preparation (2004) in \& 26 gave the property expert discretion regarding market area selection. However, judicature in this area has developed a definition of the concepts of a local and regional market, bringing them to the administrative boundaries of cities, communes, counties, and provinces.

The aim of the article is to attempt to answer the following questions:

- should legal or economic conditioning be the determinant of market area selection?

- what implication do the legal interpretations of a "local" and "regional" real estate market have on the appraisal process?

In practice, this is a very important issue since, based on well-established judicature, a usability test of proof, such as an appraisal report, is conducted in administrative proceedings, for example, for the purposes of making an administrative decision on the amount of compensation awarded for a property seized by law for a public purpose (i.a., a road). Also, judicial decisions relating to the definition of "local and regional markets" became the basis for forming an opinion on the correctness of the compiled appraisal reports.

The need to determine the proper selection of the market area and the choice of comparable markets in a situation when there is a lack of information on transactions of similar objects on a specific market has already been pointed out by BEEEJ and CELLMER (2007), who proposed the concept of assessing the scale of similarity of local real estate markets by using statistical inference procedures derived from multidimensional exploration techniques and nonparametric methods. This approach, though a good tool for searching for similarities in markets in different cities and provinces, seems unreliable in studies conducted in a single urban area because the economic indicators of a large city are hardly comparable to those of small neighboring municipalities, which are strongly associated with the city.

This paper poses the research thesis that the limits of the impact of some segments of real estate markets do not match the administrative boundaries of cities, municipalities and counties.

\section{Legal aspects of the selection of the market area}

As mentioned above, neither the provisions of the Real Estate Act (1997) nor the provisions of the Directive (2004) define the terms "local market" and "regional market". Judicial decisions formed the view that to define these terms it may be helpful to use the regulations contained in the system acts of self-governments (Department of Jurisprudence I ... 2012). Art. 6 s. 1, art. 7 s. 1 p. 4 of the Local Government Act (1990) and art. 1 of the Voivodship Authorities Act (1998) show that the word "local" includes the territory of the municipality and the county and "regional" - the area of the region (ruling of the Administrative Court in Warsaw of 29 October 2008. I SA/Wa 1204/08). This stand was supported in a number of other rulings made by Regional Administrative Courts (i.e., the ruling of the Administrative Court in Wrocław on 7 April 2009, II SA / Wr 537/08 and the ruling of the Administrative Court in Bydgoszcz on 26 October 2009, II SA / Bd 626 / 09).

The situation becomes more complicated when dealing with the appraisal of real estate located in the suburban area of the city, the location of which administratively belongs to the commune but which, functionally and spatially-speaking, is associated with the city. Such cases are numerous in Poland and, moreover, it is possible to identify districts (even with the same name) with some parts located within the city and others within the commune. The above mentioned rulings indicate that, for real estate in a suburban area, the premises of the municipality and county form its local market, while the city market, as part of an independent city district, is a regional market in relation to such a property. In preparing the appraisal, an expert must carry out an analysis of the real estate market, the scope of which is crucial for the appraisal process. Analyzing the regulations of \& 26 of the Directive (2004), the sales on the local real estate market (commune and county) are surely the first to be analyzed and only in the case of a lack of transactions can one accept transaction prices or rates of rent acquired for similar properties on the regional or domestic market.

It is in the suburban areas that a bizarre situation exists, i.e., in the case of an appraisal in locations strongly associated with the city, which are considered to be very attractive, one should refer to the commune and county markets, not to the nearby city's market, including districts in the direct neighborhood. Such thinking is rapidly becoming used by administrative procedure parties who, 
dissatisfied with the value specified in the report, file complaints with appropriate bodies by means of appeals, often resulting in the desired decision. An example of the court's ruling is that: "extending the scope of property location to the regional or domestic market is only acceptable in exceptional cases" the Ruling of SAC OSK/586/10 of 18.02.2011, in which the Court dismissed the cassation appeal on, inter alia, the grounds that the appraisal process should not include regional market real estate in the comparison (which in this case was $15 \mathrm{~km}$ away from the appraised property). It seems that this is in conflict with the economic fundamentals of appraisal, since market value as an economic category is shaped by the market and it is the market which should indicate the scope of the area of transactions under investigation. In literature (The Appraisal of Real Estate, 2001), no clear limitations of notions such as a "local" or "regional" market were found, though it is indicated that the area out of which the expert selects comparative transactions depends on the kind of property. As an example, sometimes even when possessing data from a neighboring market to appraise a given property, experts should take a wider market into consideration, which would allow them to place the appraised property in a wider market context. Doubts as to the correctness of legal guidelines in terms of area selection for market research were the motivation behind posing the research thesis.

\section{Buyers' preferences and market area selection}

Establishing market value is an attempt at objectifying the market (KUCHARSKA-STASIAK, 2011), which involves the gathering of relevant market information about similar properties, named in the Home Office (2005) and competitive against the appraised, that are not random, but similar in type, size, purpose, and especially location. Objectification of the market means that the diagnosis should be conducted by studying the preferences of buyers, because if the market (here: the buyer's market) reacts to certain factors by the amount paid for the property, the appraiser, as far as the market is concerned, is also obliged to take them into account in the appraisal process.

KUCHARSKA-STASIAK (2011) indicates that if the appraisal requires any data needed to understand, simulate and quantify the market participants' way of thinking, the utilization of market surveys, understood as formal research methods, should be a key source of information, especially market information. In their publications, ŹRÓBEK and BEŁEJ (2000), PRYSTUPA (2001), and GAWRON (2012) referred to the subject of applying qualitative techniques in comparative studies in the appraisal process. Qualitative research facilitates getting closer to the natural, real world of test subjects, hence its results are not representative for a wider population and one cannot run statistical inference based on it (NIKODEMSKA-WOŁOWIK 1999). In the case of appraisal, qualitative research is usually carried out on smaller samples of consumers or buyers, since market and property prices for the majority of its segments are of a local rather than universal nature (Prystupa 2001). A discussion on the need to introduce data based on the preferences and convictions of conscious market participants into the appraisal process was held by ALLEN and AUSTIN (2001).

In the context of the posed research thesis, research was carried out on buyers' preferences in relation to the suburban area of the city of Bydgoszcz in order to determine whether buyers find it important to take into consideration the administrative city, commune, and county boundaries and hence, whether the market area assumed in the report by the appraiser should include these boundaries.

To this end, research questionnaires were prepared and then sent out to entities dealing with the real estate market. It was deemed justified to direct questions to a group of respondents who deal with potential buyers on a daily basis, since the opinion of those operating on or entering the market is more valuable than that of those who never sold or bought any property and are not at all interested in real estate. Answers from fifty respondents were collected and an extract from the questionnaire together with the answers can be found below.

Table 1

Preferences of buyers in terms of property location on the premises of the suburban area of Bydgoszcz (extract from questionnaire)

\begin{tabular}{llllll}
\hline & Question & \multicolumn{3}{c}{ Number of responses } & Total number \\
\cline { 3 - 5 } No. & YES & NO & $\begin{array}{c}\text { DO } \\
\text { NOT } \\
\text { KNOW }\end{array}$ & $\begin{array}{c}\text { of all } \\
\text { respondents }\end{array}$ \\
\hline
\end{tabular}




\begin{tabular}{|c|c|c|c|c|c|}
\hline 1. & $\begin{array}{l}\text { When choosing the location of a } \\
\text { property for a housing investment in } \\
\text { Bydgoszcz, do you also consider } \\
\text { locations in the suburban area? }\end{array}$ & 43 & 7 & - & 50 \\
\hline 2. & $\begin{array}{l}\text { Do you consider the communes of } \\
\text { Bydgoszcz county to be a suburban } \\
\text { area? }\end{array}$ & 16 & 34 & - & 50 \\
\hline 3. & $\begin{array}{l}\text { Within the individual areas of gminas } \\
\text { are there villages which are especially } \\
\text { attractive when it comes to their location } \\
\text { and similar to location in the districts of } \\
\text { Bydgoszcz? }\end{array}$ & $\begin{array}{l}\text { (respondents } \\
\text { indicated } \\
\text { selected } \\
\text { villages - } \\
\text { fig. } 1 \text { below) } \\
\end{array}$ & - & 3 & 50 \\
\hline 4. & $\begin{array}{l}\text { Are the indicated locations of properties } \\
\text { in particular villages characterized by } \\
\text { similar levels of prices to properties in } \\
\text { the districts of Bydgoszcz? }\end{array}$ & 19 & 26 & 5 & 50 \\
\hline 5. & $\begin{array}{l}\text { When buying a housing property in a } \\
\text { suburban commune, would you pay a } \\
\text { similar price, irrespective of its location } \\
\text { (within the village) on the commune } \\
\text { premises? }\end{array}$ & $\begin{array}{l}8, \text { but } \\
\text { indicating a } \\
\text { specific } \\
\text { commune }\end{array}$ & 40 & 2 & 50 \\
\hline
\end{tabular}

Source: own study.

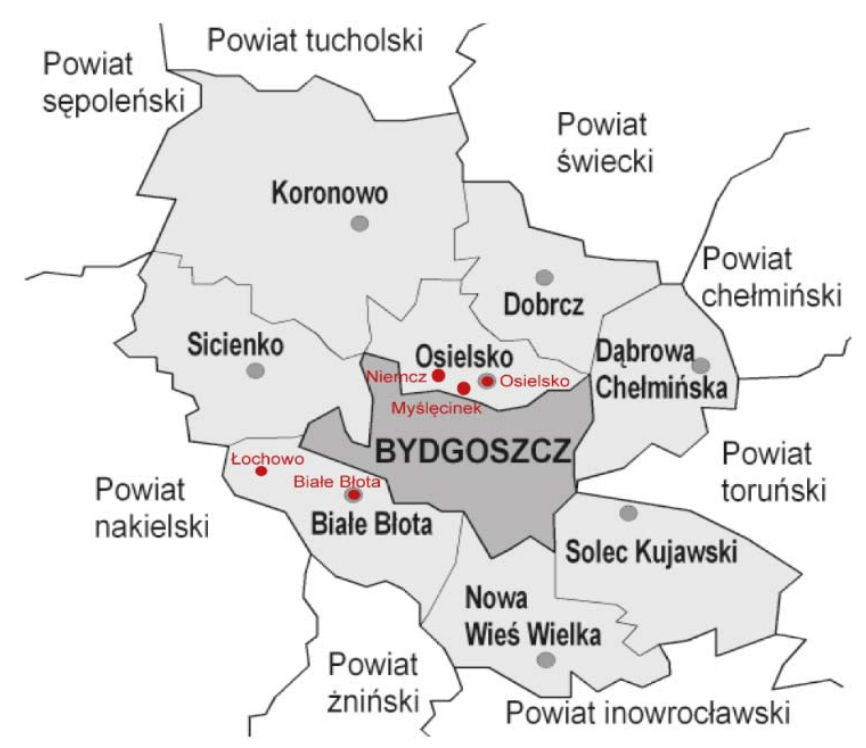

Fig. 1. Locations in the suburban area of Bydgoszcz that scored the highest amongst respondents in terms of the attractiveness of their location. Source: own study based on map:

http://pl.wikipedia.org/wiki/Plik:Powiat_bydgoski_mapa.png

The above research indicates that:

1) the suburban area, being strongly related to the city (the agglomeration center) is considered by buyers of housing properties $-86 \%$ of the respondents indicated such a possibility;

2) not all communes of Bydgoszcz county are considered a suburban area by real estate market participants $-68 \%$ of the respondents feel otherwise;

3) $94 \%$ of the respondents selected villages that are known to be similar in terms of the attractiveness of their location to those that are situated in Bydgoszcz housing districts; the top five villages have been listed according to the highest number of positive answers and are as follows: Niemcz - 80\%, Osielsko - 80\%, Białe Błota-70\%, Myślecinek - 56\%, Łochowo - 50\%;

4) $38 \%$ of the respondents believe that property prices in the chosen villages are at a similar level to those in the districts of Bydgoszcz, with $52 \%$ believing otherwise; $10 \%$ of the people surveyed 
could not specify their opinion. Such a variation of responses can mean that the market is unclear and unstable;

5) In reference to the attractiveness of the location of properties in particular communes, $80 \%$ of the respondents said that they weren't willing to pay a similar price for the same property, regardless of its location in the commune area; this means that the real estate market within the commune boundaries is diverse and cannot be treated as homogenous.

From earlier research on the attractiveness of land in some communes of the suburban zones of Bydgoszcz, we can conclude that prices of building allotments in the villages of Osielsko and Niemcz (Osielsko commune, Bydgoszcz county), which neighbor Bydgoszcz and are situated close to the city center, reach considerably higher levels than those of real estate located on the premises of the actual commune (KRAJEWSKA, 2011).

Similar tendencies on the suburban real estate market were presented by GAWRON (2012) for the Poznan agglomeration. According to the author, in most cases, the value of construction sites is dependent on their location, and because most potential buyers in search of construction sites which are to be inhabited by single families assume that they will keep working within the city, a decisive feature of the property is the commuting time, i.e., the distance and the widely understood availability of transportation. Research by GAWRON (2012) on the Poznan agglomeration shows that the prices of construction sites were clearly diversified (10-1,000 PLN/m2), with the most expensive and attractive construction sites situated in the immediate vicinity of Poznan.

Research on the suburban zone of Olsztyn (WOLNY, ŹRÓBEK, 2012) shows that the biggest intensity of use can be observed in areas situated nearest to the city, whereas the farther away from its boundaries, the smaller the intensity of use, which drops gradually to levels observed in rural areas. The value of single properties increases together with the transformation of areas, and the price of allotments depends, to a large extent, on the location factor - the distance from the city center and the availability of transportation. The farther away from the city the properties are situated, the less attractive and valuable they are to investors.

The conducted research and deliberations show that villages/village councils with are clearly preferential in terms of location, similarly to and sometimes even to a higher extent than districts of a city which constitutes the agglomeration center, can be singled out in the suburban zone. This leads us to the conclusion that, for the needs of the appraisal of properties located in suburban zones, one cannot limit the research area of the market to the administrative boundaries of a commune or county, as a local market (even if transactions are present). It should be extended to include similar urban districts which, according to the author, can create a local market. This should not be treated as a violation the law, but rather as searching for the most accurate reflection of the market. The presented research on buyers' preferences confirms the thesis that the boundaries of the effects of the real estate market do not match the administrative borders of cities, communes and counties.

\section{Example of land appraisal based on data sourced from various market areas}

When attempting to answer the question of what effects do the legal interpretations of "local" and "regional" have on the appraisal process, a case study was carried out. It involved the appraisal of land situated in the suburban area of the city of Bydgoszcz, more specifically in the village of Niemcz, in Osielsko commune, which was to be used as a road. The data used in the appraisal came from:

1) the local market, encompassing the premises within the administrative boundaries of Osielsko commune,

2) the regional market, encompassing a part of the premises of Osielsko commune (Bydgoszcz county) and the neighboring premises of the city of Bydgoszcz (Bydgoszcz City county).

The subject of the appraisal was an allotment $(X)$ with the land capacity of $2,300 \mathrm{~m}^{2}$, as part of a property destined to be turned into a public commune road - Słowackiego street in Niemcz. Allotment $X$ was shaped like a regular polygon, similar to a rectangle, and was situated on flat land. The premises from which the allotment $X$ was selected were equipped with all utilities. The property was the subject of property rights and the appraisal was done in order to specify the amount of compensation for the allotment designated to become a public road, as a part of a property which was divided following an application put in by the owner and which, under law, became the possession of the commune on the day that the decision approving the division was finalized. Market value was specified in accordance with the condition of the property on the day the decision was issued, with the 
level of prices established on the day the appraisal report was drafted, i.e., 20.05.2011.

In order to carry out the appraisal, the first subject of analyses were properties which were the subject of property rights, acquired for public use, i.e., for the construction or expansion of roads. In the investigated segment of the market, there were several "road transactions" on the premises of Osielsko commune in the years 2009 - 2011. The number of transactions involving roads has, however, been decreasing from year to year, since today, allotments are acquired in accordance with the Act of 10 April 2003, which specifies special conditions of preparing and realizing investments concerning public roads, thus with compensation and not under civil-legal contracts. A list of road transactions with allotments designated for roads in site plans, registered on the premises of Osielsko County during the analyzed study period, is featured in table 2. It contains a total of 11 transactions, with prices ranging from $69 \mathrm{PLN} / \mathrm{m}^{2}-86.47 \mathrm{PLN} / \mathrm{m}^{2}$. Prices from the premises of Niemcz village were not taken into consideration.

Next in the investigation of the road market, in order to present its wider picture and base the analyses on property prices comparable in terms of their location (not only from the Maksymilianowo and Osielsk area), the prices of road allotments situated in the northern parts of Bydgoszcz, in the immediate vicinity of Osielsko commune borders or situated in the near neighborhood - up to $10 \mathrm{~km}$ away from the commune, are featured in table 2. A similar distance between these allotments and the agglomeration center, commuting time, public transport system and nature of the surroundings results in a similarity of properties in districts of Bydgoszcz such as Fordon-Eskulapa or Myślęcinek (a district of the same name is also found in the village of Osielsko) to the appraised allotments, which indicates a possibility of including them in the analysis.

When examining buyers' preferences, the fact that $80 \%$ of the questioned respondents pointed out the similarity between the markets of Niemcz village in Osielsko commune and Bydgoszcz districts is also justified. Although the survey concerned identifying preferences in a segment of residential real estate, the appraised land designated to become a road was, in fact, situated in a residential zone and undoubtedly, the neighboring premises have an influence on its value and contribute to the location attractiveness of a given place.

The prices of land for roads in the neighboring districts of Bydgoszcz ranged from $85.45 \mathrm{PLN} / \mathrm{m}^{2}$ to $123.73 \mathrm{PLN} / \mathrm{m}^{2}$.

Table 2

Classification of transaction prices for land acquired for public roads under civil-legal agreement

\begin{tabular}{|c|c|c|c|c|c|c|c|}
\hline No. & $\begin{array}{c}\text { Date of } \\
\text { transaction }\end{array}$ & \multicolumn{2}{|c|}{$\begin{array}{c}\text { Location } \\
\text { (commune / area, street) }\end{array}$} & \multirow{2}{*}{\begin{tabular}{|c|c}
$\begin{array}{c}\text { Net price } \\
\text { of land } \\
{[z t]}\end{array}$ \\
20217 \\
\end{tabular}} & \multirow{2}{*}{$\begin{array}{c}\begin{array}{c}\text { Area of } \\
\text { land } \\
{\left[\mathrm{m}^{2}\right]}\end{array} \\
283 \\
\end{array}$} & \multirow{2}{*}{$\begin{array}{l}\begin{array}{c}\text { Price of } \\
\mathbf{1} \mathbf{~ m}^{\mathbf{2}} \\
{\left[P L N / \mathrm{m}^{2}\right]}\end{array} \\
69.00\end{array}$} & \multirow{2}{*}{\begin{tabular}{|c|c|}
$\begin{array}{c}\text { Zoning in } \\
\text { MPZP }\end{array}$ \\
C $25 \mathrm{KL}$ \\
\end{tabular}} \\
\hline & 2010-07-29 & Osielsko Co. & Maksymilianowo & & & & \\
\hline & 2010-06-02 & Osielsko Co. & Maksymilianowo & 20079 & 291 & 69.00 & $\mathrm{C} 25 \mathrm{KL}$ \\
\hline & $2010-07-29$ & Osielsko Co. & Maksymilianowo & 20631 & 299 & 69.00 & C $25 \mathrm{KL}$ \\
\hline & 2010-05-24 & Osielsko Co. & Maksymilianowo & 21114 & 306 & 69.00 & C $25 \mathrm{KL}$ \\
\hline & . 2010-09-22 & Osielsko Co. & Maksymilianowo & 5126 & 66 & 77.67 & A $16 \mathrm{KL}$ \\
\hline & 2010-09-23 & Osielsko Co. & Maksymilianowo & 3961 & 51 & 77.67 & A $16 \mathrm{KL}$ \\
\hline & 2010-09-23 & Osielsko Co. & Maksymilianowo & 4816 & 62 & 77.67 & A $16 \mathrm{KL}$ \\
\hline & . 2010-09-22 & Osielsko Co. & Maksymilianowo & 4816 & 62 & 77.67 & A $16 \mathrm{KL}$ \\
\hline & 2010-09-23 & Osielsko Co. & Maksymilianowo & 5437 & 70 & 77.67 & A $16 \mathrm{KL}$ \\
\hline & 0. 2010-06-28 & Osielsko Co. & Osielsko & 37122 & 430 & 86.33 & KD22 \\
\hline \multirow{2}{*}{\multicolumn{2}{|c|}{ 11.2011-02-08 }} & Osielsko Co. & Osielsko & 202686 & 2344 & 86.47 & KD 42 \\
\hline & & \multicolumn{2}{|l|}{ BYDGOSZCZ } & & & & \\
\hline \multicolumn{2}{|c|}{$12.2009-12-16$} & \begin{tabular}{l}
\multicolumn{1}{c}{ Bydgoszcz } \\
Fordon \\
Eskulapa/390 \\
\end{tabular} & Trybowskiego & 64000 & 749 & 85.45 & S.63.KL \\
\hline
\end{tabular}




\begin{tabular}{|c|c|c|c|c|c|c|}
\hline 13.2009-10-29 & $\begin{array}{l}\text { Bydgoszcz } \\
\text { Fordon } \\
\text { Eskulapa/389 }\end{array}$ & - Pod Skarpą & 50000 & 563 & 88.81 & S.61 KL \\
\hline $14.2009-12-10$ & $\begin{array}{l}\text { Bydgoszcz } \\
\text { Fordon } \\
\text { Eskulapa/390 }\end{array}$ & - Pod Skarpą & 3240 & 36 & 90.00 & S.60. KL \\
\hline $15.2010-07-24$ & \begin{tabular}{l}
\multicolumn{1}{c}{ Bydgoszcz } \\
Fordon \\
Eskulapa/389
\end{tabular} & - Pod Skarpą & 50600 & 506 & 100.00 & S $61 \mathrm{KL}$ \\
\hline $16.2010-06-18$ & \begin{tabular}{l}
\multicolumn{1}{c}{ Bydgoszcz } \\
Fordon \\
Eskulapa/390
\end{tabular} & - Żemojtela & 27300 & 273 & 100.00 & S $79 \mathrm{KL}$ \\
\hline $17.2010-07-09$ & $\begin{array}{l}\text { Bydgoszcz } \\
\text { Myślęcinek }\end{array}$ & Siodłowa & 7300 & 59 & 123.73 & $6 \mathrm{KD}$ \\
\hline
\end{tabular}

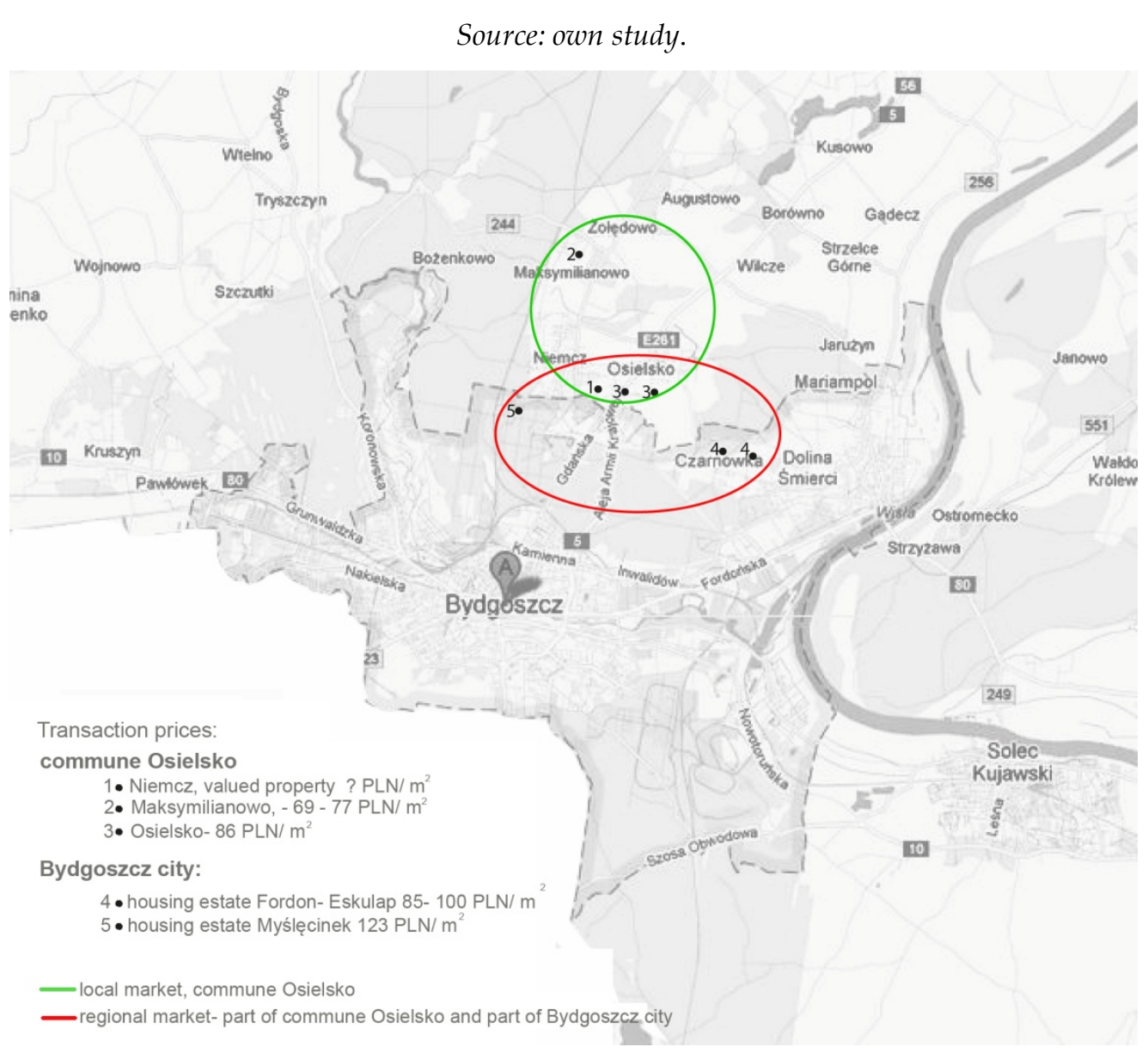

Fig. 2. Spatial distribution of transaction prices. Source: own study.

The two variants (I and II) of land appraisal were performed with a comparative approach, by a method of pair comparison, taking into account data from various parts of the market in each comparison.

3.1 Land appraisal based on data from the part of the market encompassing only Osielsko commune - variant I

Unit prices from the considered research area encompassing the 11 road transactions (pos. 1-11, table 2) ranged from:

$$
\mathrm{C}_{\min }=\text { 69.00 PLN } / \mathrm{m}^{2}, C_{\max }=86.47 \mathrm{PLN} / \mathrm{m}^{2}, \Delta \mathrm{C}=17.47 \mathrm{PLN} / \mathrm{m}^{2}
$$

Three of the most similar properties were selected from the considered range for the analysis of pair comparison, namely: 
No. 9 - MAKSYMILIANOWO, allotment land with a surface of $70 \mathrm{~m}^{2}$, unit price $\mathrm{C}_{\mathrm{j}}=77.67 \mathrm{PLN} / \mathrm{m}^{2}$.

NO. 10 - OSIELSKO, allotment land with a surface of $430 \mathrm{~m}^{2}$, unit price $C_{\mathrm{j}}=86.33 \mathrm{PLN} / \mathrm{m}^{2}$.

NO. 11 - OSIELSKO, allotment land with a surface of $2,344 \mathrm{~m}^{2}$, unit price $C_{j}=86.47 \mathrm{PLN} / \mathrm{m}^{2}$.

It should be emphasized that no transactions were noted in the Niemcz village and only two in Osielsk; this fact was included in the analysis. The market for this segment is thus, largely limited and it was difficult to find any pieces of real estate which were similar to each other in terms of both, location as well as size. Consequently, it was decided that the third piece of real estate in question, coming from Maksymilianów, will be characterized by the most current transaction date.

Taking into consideration the features of real estate such as: its general location and neighboring areas, the availability of utilities in the surrounding areas, the surface area of the land, and the organizational assets of the land, an assessment of the features of allotment $X$ as a part of the real estate was made and a comparative analysis of the allotment in question was carried out in comparable pairs $(\mathrm{X}-9, \mathrm{X}-10, \mathrm{X}-11)$. The unit value of the land was specified at: $\mathrm{Wj}=86.40 \mathrm{PLN} / \mathrm{m}^{2}$. The market value of allotment $X$ with a surface area of $2,300 \mathrm{~m}^{2}$ in variant I amounted to:

$$
\text { WR }(\mathrm{I})=86.40 \mathrm{PLN} / \mathrm{m}^{2} \times 2,300 \mathrm{~m}^{2}=198.720 \text { PLN }
$$

\subsection{Appraisal of land based on data from the part of the market encompassing Osielsko commune and the neighboring premises of the city of Bydgoszcz - variant II}

Unit prices from the considered research area encompassing 9 road transactions (pos. 17, table 2) ranged from:

$$
\mathrm{C}_{\min }=\text { 85.45 PLN } / \mathrm{m}^{2}, \quad C_{\max }=123.73 \mathrm{PLN} / \mathrm{m}^{2}, \Delta \mathrm{C}=38.28 \mathrm{PLN} / \mathrm{m}^{2}
$$

From the considered range, three of the most similar real estate properties were selected for the pair comparison analysis, namely:

NO. 18 - MYŚLĘCINEK, allotment land with a surface of $59 \mathrm{~m}^{2}$, unit price $C_{\mathrm{i}}=123.73 \mathrm{PLN} / \mathrm{m}^{2}$.

NO. 10 - OSIELSKO, allotment land with a surface of $430 \mathrm{~m}^{2}$, unit price $C_{j}=86.33 \mathrm{PLN} / \mathrm{m}^{2}$.

NO. 11 - OSIELSKO, allotment land with a surface of $2,344 \mathrm{~m}^{2}$, unit price $C_{j}=86.47 \mathrm{PLN} / \mathrm{m}^{2}$.

Properties no. 10 and 11 were selected just like in variant 1, however, the third property, no. 18, was chosen based on the fact that it was the most similar to the appraised one in terms of its location out of all the properties listed in table 2 (merely $2 \mathrm{~km}$ away from the appraised property, with the same main access road); moreover, it was also in the same neighborhood and possessed the same utilities. The only thing that was different was the surface area.

Taking into consideration real property features such as: its general location and neighboring areas, the availability of utilities in the surrounding areas, the surface area of the land, and the organizational assets of the land, an assessment of the features of allotment $X$ as part of the real estate was made and a comparative analysis of the allotment in question was carried out in comparable pairs $(\mathrm{X}-18, \mathrm{X}-10, \mathrm{X}-11)$. The unit value of the land was specified at: $\mathrm{Wj}=97.56 \mathrm{PLN} / \mathrm{m}^{2}$. The market value of allotment $X$ with the surface area of $2,300 \mathrm{~m} 2$ in variant II amounted to:

$$
\text { WR (II) }=97.56 \mathrm{PLN} / \mathrm{m}^{2} \times 2,300 \mathrm{~m}^{2}=224.388 \mathrm{PLN}
$$

\subsection{Analysis of acquired results}

In the analyzed case, considering a different area of the market as the basis for the appraisal of land in the comparative approach triggered a change in its value by 25.668 PLN, that is by approximately $13 \%$. The number of compared transactions and information on the features of similar real estate properties were actual market proofs that occurred during the examination of prices, and no others were noted. They concerned the "roads" market, which is often limited and unclear, which required the scope of its research area to be extended.

In variant $\mathrm{I}$, the surface area of the land was selected in accordance with provisions included in judicature and encompassed the local market - the Osielsko commune premises.

In variant II, the market research area was extended to include locations which neighbored Osielsko commune but administratively belonged to Bydgoszcz; in other words, when referring back to the nomenclature and judicature, the basis for the appraisal was the regional market, since the data came from various counties (Bydgoszcz county and Bydgoszcz City county).

Because legal conditioning primarily points to the necessity of basing the appraisal process on data from the local market, the value of W(I) $=198.720$ PLN specified in variant I seems to be the most accurate from the legal point of view. On the other hand, the value specified in variant II, which is 
equal to 224.338 PLN, reflects the behavior of the real estate market participants and, therefore, stems from economic conditioning present on this market. The reason for the considered market area in variant II is the fact that the village of Niemcz is characterized by a higher degree of urbanization as compared to Maksymilianowo village (where no road transactions were noted), thus it was advisable to exclude the transactions from this market. It is worth noting that the land market in the villages of Osielsko and Niemcz has the highest level of prices as compared with the rest of the rural markets in Osielsko commune (Krajewska, 2011) and, moreover, is comparable with Bydgoszcz. The above was confirmed by real estate buyers in a survey (compare answers to question 3 in the survey, Tab. 1). Therefore, taking transaction prices for the appraisal also from the Bydgoszcz area is justified.

As it was proven in the previous chapter, the real estate market is ruled differently and does not depend on the administrative boundaries of cities, communes, or counties. It is, therefore, necessary to point out that the market value which can constitute the basis for calculating the amount of compensation for land acquired for a public road is that of W(II) $=224.388$ PLN.

\section{Summary}

The proper selection of an area for investigating a market in order to appraise the value of real estate is a key element of every appraisal. In Polish legislation dealing with the economics of real estate, notions such as "local market" and "regional market" remain undefined, leaving the issue at the discretion of the real estate appraiser which, according to the author, is correct and in accordance with mainstream appraisal procedures throughout the world. Court judicature in Poland has, however, developed some definitions of these notions, which has contributed to the increase of legal interference in the appraisal process, tightening the criteria of market selection and thus, in many cases, distorting the determined market value. Since it is unquestionable that market value is an economic category, it should stem from the market and account for the economic determinants of appraisal. That is why the selection of the research area should be determined on the basis of economic analysis. Research on buyers' preferences, which enables the research area to be diagnosed even in conditions of a limited market, i.e., one with a very small number of transactions, can be very helpful for such analyses. The issue concerning determining the scope of the area of the investigated market is particularly important and current, especially for the suburban zones of large cities, where structures characteristic of villages and cities overlap and it is hard to identify a clear urban or socioeconomic boundary between city and village, and consequently, demarcate between the economic potential of the real estate market. As shown in practice, many segments of real estate markets in individual communes that belong to urban agglomerations are poorly developed and it is highly unadvisable to limit them by legal interpretations. This can lead to the distortion of the market value of real estate and have further repercussions in establishing, for example, the amount of compensation, tax calculation and fees, etc. The case under investigation in this article was used to practically illustrate this problem, with research on preferences aimed at supplying proof that the impact of the real estate market extends beyond the administrative boundaries of cities, communes or counties.

The article hopes to raise awareness, not only of market players but also adjudicating bodies, that the mere selection of market information and knowledge of its behavior can provide clues as to the proper choice of the research area. This concept of "feeling the market" is an extremely important element of each appraisal (Real Estate Appraisal, 2000) and is carried out by a real estate appraiser in a valuation survey.

\section{Bibliography}

Allen, M.T., Austin, G.W., 2001, The Role of Formal Survey Research Methods in the Appraisal Body of Knowledge, The Appraisal Journal, October.

BEŁEJ M., CELLMER R., 2007, Koncepcja oceny skali podobieństwa lokalnych rynków nieruchomości na potrzeby gospodarki przestrzennej, [w]: Studia i Materiały TNN, Volume 15, number 3-4, Olsztyn.

DEPARTAMENT ORZECZNICTWA I W MinisTERSTWIE TRANSPORTU, BUDOWNICTWA I GOSPODARKI MORSKIEJ, 2012, Odszkodowania za nieruchomości przeznaczone na cele inwestycji liniowych, Warszawa.

GAWRON H., 2012, Wptyw cech fizycznych dziatek na ceny gruntów budowlanych w aglomeracji miejskiej (na przykładzie aglomeracji poznańskiej), Studia i Materiały TNN, Volume 20, number 2, Olsztyn, s. 47-57. 
KRAJEWSKA M. 2011, Ksztattowanie się wartości gruntów w strefie podmiejskiej miasta Bydgoszczy, Zeszyty naukowe nr 192: Stan i tendencje rozwoju rynku nieruchomości, Wydawnictwo Uniwersytetu Ekonomicznego w Poznaniu, s. 70-80.

KRAJEWSKA M., 2011, Uwarunkowania planistyczne a wartość nieruchomości na rynku, [w]: SIEMIŃSKA E. (RED), Inwestowanie na rynku nieruchomości, Wydawnictwo POLTEXT, Warszawa, s. 149-179.

KUCHARSKA-STASIAK E., 2011, Odwzorowania rynku w procesie wyceny, Zeszyty naukowe nr 192: Stan i tendencje rozwoju rynku nieruchomości, Wydawnictwo Uniwersytetu Ekonomicznego w Poznaniu, s. 7-18.

MięDZYNARODOWE STANDARDY WYCENY (wyd. pol.), 2005, PFSRzM, IVSC, Warszawa.

NiKODEMSKA-WOŁOWIK A. M., 1999, Jakościowe badania marketingowe, PWE, Warszawa, s. 14.

POWSZECHNE KRAJOWE ZASADY WYCENY, PFSRzM, Warszawa.

PRYSTUPA M., 2001, Wycena nieruchomości przy zastosowaniu podejścia porównawczego, PFSRzM, Warszawa, s. 31-44.

The Appraisal of ReAL Estate 12 th EDITION, 2001, Appraisal Institute, USA.

WOLNY A., ŹRÓBEK R., 2012, Proces przeksztatcania przestrzeni na obszarach o największej aktywności na rynku nieruchomości, Studia i Materiały TNN, Volume 20, number 2, Olsztyn, s. 33-46.

WYCENA NIERUCHOMOŚCI, 2000, wyd. polskie, PFSRzM, Warszawa.

ŹRÓBEK S., BEŁEJ M, 2000, Podejście porównawcze w szacowaniu nieruchomości, EDUCATERRA, Olsztyn, s. 19-32.

ROZPORZĄDZENIE Rady Ministrów z dnia 21.09.2004 r. w sprawie wyceny nieruchomości i sporządzania operatu szacunkowego, (Dz. U. Nr 207 z 2004, poz. 2109).

USTAWA z dnia 21.08.1997 r. o gospodarce nieruchomościami, (tekst jednolity: Dz. U. Nr 102 z 2010, poz. 651 ze zm.).

USTAWA z dnia 08.03.1990 r. o samorządzie gminnym, (tekst jednolity: Dz. U. Nr 142 z 2001, poz. 1591 ze zm.).

UstAWA z dnia 05.06.1998 r. o samorządzie powiatowym, (tekst jednolity: Dz. U. Nr 142 z 2001, poz. 1592 ze zm.).

UstAWA z dnia 05.06.1998 r. o samorządzie województwa, (tekst jednolity: Dz. U. Nr 142 z 2001, poz. 1590 ze zm.). 